\title{
Effect of external environmental factors on the technological and physical-mechanical properties of silkworm
}

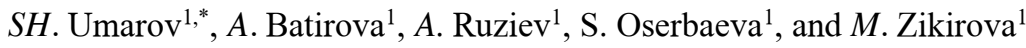 \\ ${ }^{1}$ Tashkent State Agrarian University, University str., 2, Tashkent province, Uzbekistan, 100140
}

\begin{abstract}
In this article, we have studied the extent to which the technological performance of mulberry silkworms on the industrial hybrids "Musaffo Tola 1" and "Musaffo Tola 2" changes during the hot summer days and these hybrids retain their potential even in adverse stress conditions. Import varieties of "Jingsong x Hoayou" and "Hoayou x Jingsong" hybrid combinations were selected as control hybrids. This Chinese hybrid is the most imported hybrid in Uzbekistan. The purpose of our experiments is to assess the resistance of domestic and import varieties of hybrids to high temperatures on the basis of technological indicators. Changes in the biological performance of import varieties of and domestic hybrids under stress conditions, in particular, a decrease in the viability of worms, an increase in the percentage of deaf and black cocoons, and changes in technological properties were studied.
\end{abstract}

\section{Introduction}

The demand for high-quality and competitive silk products in the world silk market places high demands on the quality of raw silk and raw silk grown in our country. The main goal is to meet the requirements of the raw silk textile industry [1]. If we analyze the geographical location of cocoon-growing provinces and districts, silkworms are raised and cocoons are grown in almost all provinces.

In world silk, special attention is paid to the technological performance of cocoon raw materials. Because the range and quality of silk products depend mainly on the technological parameters of silk fiber $[2,3]$. Technological traits depend primarily on the genotype of the silkworm breed and hybrids being cared for, followed by paratypical factors. Especially in spring, summer and autumn, silk fibers made from cocoons made of silk are very different from each other. In this regard, the extent to which the extremely high summer temperatures affect the silk raw material obtained from local hybrids of silkworms is of particular scientific and practical importance [3, 4].

In their study, such scientists studied the size and physical and mechanical properties of the hybrid cocoon Navruz-1 [5-8]. The viability of the hybrid was around $89-90 \%$, the viability of the egg was $96-98 \%$, the average length of the cocoon shell was $35.3 \mathrm{~mm}$, the diameter was $19.2 \mathrm{~m}$, and $48 \%$ was of large caliber. At the same time, when studying the

* Corresponding author: ushavkat@mail.ru 
technological parameters of these hybrid cocoons, it is recognized that their silkworm $56 \%$, wormwood $-78.1 \%$, continuous length - $706 \mathrm{~m}$, and the yield of raw silk - $43.7 \%$. $3 \%$ reported higher raw silk output [1-3].

Simultaneously, the yield of silk yarn decreased by $36.2 \%$, spinning - by $70.6 \%$, and the percentage of crushing of cocoons decreased by 2 times [4-6]. In their research, a group of Indian scientists have created silkworm breeds that are resistant to different tropical climates of the country and have been able to adapt the identified polyvoltin $\mathrm{x}$ bivoltin hybrids to tropical climates. The researchers studied the biological and productivity properties of silkworms under different temperature and humidity conditions in the creation of heat-resistant hybrids and recommended to produce the most suitable ones [7-10].

\section{Materials and methods}

In our study, we studied the extent to which the technological performance of mulberry silkworms on the industrial hybrids "Musaffo Tola 1" and "Musaffo Tola 2" changes during the hot summer days, and these hybrids retain their potential even in adverse stress conditions. Import varieties of "Jingsong x Hoayou" and "Hoayou x Jingsong" hybrid combinations were selected as control hybrids. This Chinese hybrid is the most imported hybrid in Uzbekistan. The purpose of our experiments is to assess the resistance of domestic and import varieties of hybrids to high temperatures on the basis of technological indicators. Biological parameters of import varieties of and domestic hybrids have been shown to change under stress conditions, in particular, to reduce the viability of worms and to increase the percentage of deaf and dumb cocoons. But the technological properties of these hybrids under abnormally hot conditions were studied for the first time.

\section{Results and discussion}

To achieve the above goal, in 2019-2020, the local zoning of silkworms "Musaffo Tola 1", "Musaffo Tola 2" and import varieties of "Jingsong x Hoayou" and "“"Hoayou x Jingsong"" hybrids will be available in the spring as usual, as well as in the hot period of July were cared for and cocoons were grown. Of course, as expected, the weight of the spring cocoons was heavier than that of the cocoons obtained during the warm period. The initial analysis of the cocoons obtained for the experiments began with the determination of their geometric characteristics. The results obtained are presented in Table 1.

The technological parameters obtained in Table 1 showed that the shape of the cocoon did not change regardless of the season in which all the hybrids were cared for. That is, local and import varieties of hybrids were found to have an oval shape. At the same time, the coefficient of elasticity of the cocoons was shown to be absolutely the same $-0.9 \mathrm{Cb}$. The volume ratio is the same in both summer and spring - $0.65 \mathrm{fv}$. 
Table 1. Analysis of the geometric parameters of the cocoon (2019-2020)

\begin{tabular}{|c|c|c|c|c|c|c|c|c|c|c|c|}
\hline \multirow{2}{*}{ \# } & \multirow{2}{*}{$\begin{array}{c}\text { Silkworm } \\
\text { species }\end{array}$} & \multirow{2}{*}{ 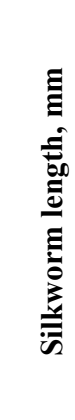 } & \multicolumn{3}{|c|}{$\begin{array}{c}\text { Diameter of } \\
\text { silkworm parts, } \\
\text { mm }\end{array}$} & \multirow{2}{*}{  } & \multirow{2}{*}{ లัँ } & \multirow{2}{*}{ 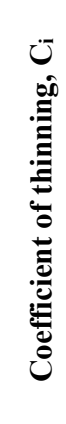 } & \multirow{2}{*}{ 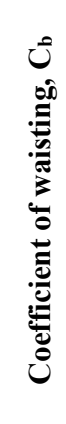 } & \multirow{2}{*}{ 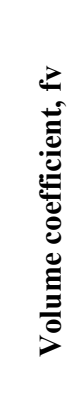 } & \multirow{2}{*}{ 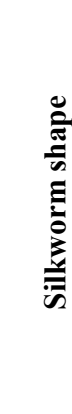 } \\
\hline & & & $\mathrm{d}_{\text {head }}$ & $\mathrm{d}_{\text {tail }}$ & $\mathrm{d}_{\text {waist }}$ & & & & & & \\
\hline 1 & $\begin{array}{l}\text { "Musaffo } \\
\text { Tola 1" } \\
\text { (spring) - } \\
\text { Tashkent }\end{array}$ & 34.0 & 17.9 & 18.8 & 19.4 & 18.3 & med. & 1.9 & 0.9 & 0.65 & oval \\
\hline 2 & $\begin{array}{l}\text { "Musaffo } \\
\text { Tola 2" } \\
\text { (spring) - } \\
\text { Tashkent }\end{array}$ & 33.5 & 16.8 & 17.6 & 19.3 & 17.2 & med. & 2.0 & 0.9 & 0.65 & oval \\
\hline 3 & $\begin{array}{l}\text { "Musaffo } \\
\text { Tola 1" } \\
\text { (summer) - } \\
\text { Tashkent }\end{array}$ & 32.1 & 14.3 & 15.1 & 17.9 & 14.7 & small & 2.2 & 0.9 & 0.65 & oval \\
\hline 4 & $\begin{array}{l}\text { "Musaffo } \\
\text { Tola 2" } \\
\text { (summer) - } \\
\text { Tashkent }\end{array}$ & 32.4 & 17.1 & 18.0 & 18.5 & 18 & med. & 1.9 & 0.9 & 0.65 & oval \\
\hline 5 & $\begin{array}{c}\text { "Jingsong x } \\
\text { Hoayou" } \\
\text { (summer) - } \\
\text { Bukhara }\end{array}$ & 28.7 & 13.9 & 14.5 & 15.0 & 14.2 & small & 2.0 & 0.9 & 0.65 & oval \\
\hline 6 & $\begin{array}{l}\text { "Jingsong x } \\
\text { Hoayou" } \\
\text { (summer) - } \\
\text { Ferghana }\end{array}$ & 28.4 & 13.3 & 14.1 & 15.0 & 13.7 & small & 2.1 & 0.9 & 0.65 & oval \\
\hline
\end{tabular}

The caliber of the cocoons plays an important role in obtaining quality silk fiber. Because the highest quality and flat silk fiber is obtained from medium-caliber cocoons. The cocoons we gained in the spring and summer differ in caliber from each other. The "Musaffo Tola 1" hybrid produced medium-caliber cocoons in the spring and small-caliber cocoons in the summer. "Jingsong x Hoayou", an import varieties of hybrid with the same genotype, breeds small-caliber cocoons both in the extremely hot conditions of Bukhara province and in the more temperate conditions of Fergana province. This, in turn, indicates that the effect of genes that control the adaptability of hybrids is significantly reflected in the hybrid "Musaffo Tola 2".

Regarding the analysis of the length of the cocoon shell, it can be said that the import varieties of hybrid had almost the same cocoon length in two provinces that differed sharply from each other - 28.7 and $28.4 \mathrm{~mm}$. The cocoon lengths of our local hybrids did not differ significantly from each other in spring and summer $(34.0-3.5 \mathrm{~mm}$ and $32.1-32.4$ $\mathrm{mm}$ ). 
There is a significant difference in the diameter of the cocoon parts in the hybrid "Musaffo Tola 1", ie the diameter of the cocoons in the spring is larger than in the summer. However, the difference in the diameter of the cocoons of the hybrid "Musaffo Tola 2" is insignificant. As for the import varieties of hybrid, this figure is almost the same in the two different provinces.

From the above analysis, it can be concluded that high temperature has a direct effect on the geometric parameters of the cocoons, and these parameters, of course, to some extent affect the process of cocooning.

Subsequent indicators that need to be analyzed include cocoon components. Silktechnologists have always been faced with the problem of spinning cocoons and increasing the yield of raw silk. Therefore, in cocoon processing plants, cocoons are sorted several times. Because cocoons grown in different conditions are brought to one enterprise. The biology of silkworms is such that, regardless of the province and climatic conditions in which the worm is kept, optimal hygrothermal conditions must be created. However, good conditions are not always created, and as a result, cocoons with different components are grown from the same hybrid. Table 2 and Figure 1 provide an analysis of the components of hybrid cocoons maintained in the spring and summer seasons of 2019-2020.

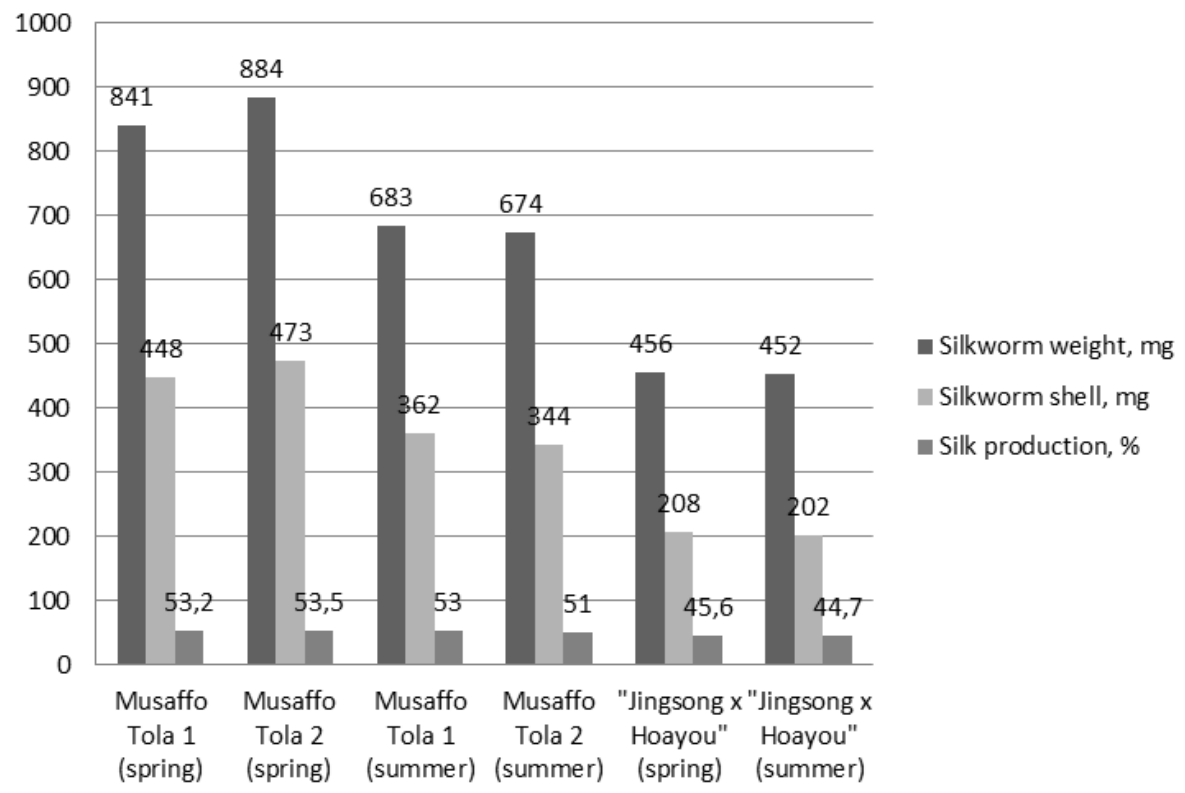

Fig. 1. Analysis of the formation of silkworm cocoon components

From the data in Table 2 and Figure 1, it can be seen that the figures obtained in the spring and summer seasons differ from each other. The silk of the cocoons decreased in the summer compared to the spring period. In the hybrids "Musaffo Tola 1" and "Musaffo Tola 2 " in the spring this figure was $55.2 \%-54.8 \%$, in the summer it was $53.9 \%-50.5 \%$ and $1.3-$ 5 , A decrease of $3 \%$ was observed. The silk content of cocoons of import varieties of hybrids in relatively warm conditions (Bukhara province) was $47.6 \%$ and in more favorable conditions of Fergana province $46.5 \%$.

If we focus on dry cocoon weight, the summer hot temperature in all hybrids led to a decrease in dry cocoon weight. In "Musaffo Tola 1" and "Musaffo Tola 2", the levels were $772 \mathrm{mg}$ and $777 \mathrm{mg}$ in spring and $656 \mathrm{mg}$ and $668 \mathrm{mg}$ in summer, respectively. A similar decline was observed in the import varieties of hybrid. 
Table 2. Analysis of the formation of silkworm cocoon components (2019-2020)

\begin{tabular}{|c|c|c|c|c|c|c|c|c|c|c|c|}
\hline \multirow[b]{2}{*}{$\#$} & \multirow[b]{2}{*}{$\begin{array}{l}\text { Silkworm } \\
\text { species }\end{array}$} & \multirow{2}{*}{ 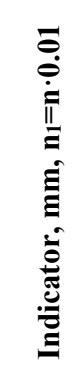 } & \multirow{2}{*}{ 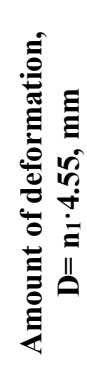 } & \multirow{2}{*}{ 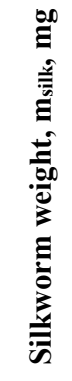 } & \multicolumn{2}{|c|}{$\begin{array}{c}\text { Silkworm } \\
\text { shell }\end{array}$} & \multicolumn{2}{|c|}{ Worm skin } & \multicolumn{2}{|c|}{ Cocoon } & \multirow{2}{*}{ 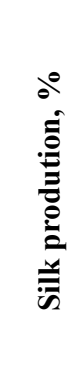 } \\
\hline & & & & & mg & $\%$ & $\mathbf{m g}$ & $\%$ & $\mathbf{m g}$ & $\%$ & \\
\hline 1 & $\begin{array}{l}\text { "Musaffo } \\
\text { Tola 1" } \\
\text { (spring) - } \\
\text { Tashkent }\end{array}$ & 0.22 & 1.00 & 772 & 425 & 55.2 & 19 & 2.5 & 328 & 42.3 & 55.2 \\
\hline 2 & $\begin{array}{l}\text { "Musaffo } \\
\text { Tola 2" } \\
\text { (spring) - } \\
\text { Tashkent }\end{array}$ & 0.18 & 0.84 & 777 & 425 & 54.8 & 14 & 1.8 & 338 & 43.4 & 54.8 \\
\hline 3 & $\begin{array}{l}\text { "Musaffo } \\
\text { Tola 1" } \\
\text { (summer) - } \\
\text { Tashkent }\end{array}$ & 0.20 & 0.93 & 656 & 353 & 53.9 & 13 & 2.0 & 290 & 44.1 & 53.9 \\
\hline 4 & $\begin{array}{c}\text { "Musaffo } \\
\text { Tola 2" } \\
\text { (summer) - } \\
\text { Tashkent } \\
\end{array}$ & 0.19 & 0.86 & 668 & 337 & 50.5 & 13 & 1.9 & 318 & 47.6 & 50.5 \\
\hline 5 & $\begin{array}{l}\text { "Jingsong x } \\
\text { Hoayou" } \\
\text { (summer) - } \\
\text { Bukhara }\end{array}$ & 0.20 & 0.93 & 390 & 185 & 47.6 & 16 & 4.0 & 189 & 48.4 & 47.6 \\
\hline 6 & $\begin{array}{l}\text { "Jingsong } \mathrm{x} \\
\text { Hoayou" } \\
\text { (summer) - } \\
\text { Ferghana } \\
\end{array}$ & 0.20 & 0.92 & 373 & 173 & 46.5 & 16 & 4.2 & 184 & 49.3 & 46.5 \\
\hline
\end{tabular}

The change in cocoon shell weight was observed to decrease from $425 \mathrm{mg}, 425 \mathrm{mg}$ to $353 \mathrm{mg}, 337 \mathrm{mg}$ in proportion to the cocoon weight. The performance of the import varieties of hybrid differed by $12 \mathrm{mg}$ in Bukhara and Fergana provinces, and this difference is almost insignificant, indicating the strength of this mark in these import varieties of hybrid.

The amount of deformation of the cocoon indicates that the temperature and climatic conditions do not affect the change in this character. The size of the cocoon in summer and spring is $1.00-0.93 \mathrm{~mm}$; $0.84-0.86 \mathrm{~mm}$; the presence of $0.92-0.93 \mathrm{~mm}$ confirms the above conclusion. A similar conclusion was observed in the indicator, i.e. the resistance to hardening or crushing of the cocoon shell during the summer and spring seasons - the hardness has hardly changed. 
Cocoon shell granularity is one of the important technological indicators. Typically, cocoon shell granulation depends on the genotype of the silkworm, with small and medium cocoon breeds with fine granularity, and large-caliber cocoons with large granulation. In the course of our research work, it was found out how high temperature can affect the cocoon shell, granular properties. Table 3 shows the granularity of cocoons of experimental hybrids grown in spring and summer.

In order to accurately determine the granularity of the cocoon shell, we calculated the number of bumps at the level of $1 \mathrm{~cm} 2$ at the apex, side of the upper and lower hemispheres of the cocoon shell, and at the waist of the cocoon shell. Based on these indicators, the average grain size of the cocoon shell was determined for each hybrid. The analysis of the indicators in Table 3 showed that hot summer conditions lead to an increase in the granularity of the cocoon shell, i.e. the number of bumps at the level of $1 \mathrm{~cm}^{2}$. This fact was clearly seen in the summer cocoons of "Musaffo Tola 1" and "Musaffo Tola 2" (51 pieces; 51 pieces).

Table 3. Indicators of granular properties of cocoon shell (2019-2020)

\begin{tabular}{|c|c|c|c|c|c|c|c|c|}
\hline \multirow{3}{*}{$\#$} & \multirow{3}{*}{$\begin{array}{l}\text { Silkworm } \\
\text { species }\end{array}$} & \multirow{3}{*}{ 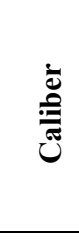 } & \multicolumn{6}{|c|}{ Granularity, granules/cm ${ }^{2}$} \\
\hline & & & \multicolumn{2}{|c|}{$\begin{array}{l}\text { Diameter of the } \\
\text { upper hemispheres }\end{array}$} & \multicolumn{2}{|c|}{$\begin{array}{l}\text { Diameter of the } \\
\text { lower hemispheres }\end{array}$} & \multirow{2}{*}{$\frac{\vec{n}}{\pi}$} & \multirow{2}{*}{ 过 } \\
\hline & & & Apex & Side wall & Apex & Side wall & & \\
\hline 1 & $\begin{array}{l}\text { "Musaffo } \\
\text { Tola 1" } \\
\text { (spring) - } \\
\text { Tashkent }\end{array}$ & med. & 42 & 43 & 44 & 43 & 47 & 44 \\
\hline 2 & $\begin{array}{l}\text { "Musaffo } \\
\text { Tola 2" } \\
\text { (spring) - } \\
\text { Tashkent }\end{array}$ & med. & 38 & 39 & 40 & 41 & 40 & 40 \\
\hline 3 & $\begin{array}{c}\text { "Musaffo } \\
\text { Tola 1" } \\
\text { (summer) - } \\
\text { Tashkent } \\
\end{array}$ & small & 51 & 50 & 50 & 51 & 51 & 51 \\
\hline 4 & $\begin{array}{l}\text { "Musaffo } \\
\text { Tola 2" } \\
\text { (summer) - } \\
\text { Tashkent }\end{array}$ & med. & 50 & 50 & 50 & 52 & 52 & 51 \\
\hline 5 & $\begin{array}{l}\text { "Jingsong x } \\
\text { Hoayou" } \\
\text { (summer) - } \\
\text { Bukhara }\end{array}$ & small & 44 & 43 & 45 & 43 & 46 & 44 \\
\hline 6 & $\begin{array}{l}\text { "Jingsong x } \\
\text { Hoayou" } \\
\text { (summer) - } \\
\text { Ferghana }\end{array}$ & small & 39 & 38 & 38 & 36 & 37 & 38 \\
\hline
\end{tabular}

This number was slightly lower in the spring (44 units; 40 units) and varied to 7-11 units. The hot climate of Bukhara also contributed to the increase in cocoon granulation of import varieties of hybrids (44). The more bumps on the surface of $1 \mathrm{~cm}^{2}$ cocoon shell, the more granular they become. This situation is explained by the fact that the high temperature 
increased the dynamics of the movement of the octopus during the cocoon wrapping of worms.

The physical and mechanical properties of the cocoon shell are also of great importance in accelerating the cocooning process and increasing the yield of raw silk. These physicomechanical parameters include shell thickness, density, strength, and porosity. The geometric and structural properties of the cocoon shell are not the same in all cocoons and vary by province. In particular, these indicators can be significantly affected by the hygrothermal regime during the feeding of silkworms. Table 4 shows the thickness and weight of the cocoon shell.

Table 4. Analysis of physical and mechanical properties of silkworm cocoon shell (2019-2020)

\begin{tabular}{|c|c|c|c|c|c|c|c|c|c|c|c|}
\hline \multirow{3}{*}{ \# } & \multirow{3}{*}{$\begin{array}{c}\text { Silkworm } \\
\text { species }\end{array}$} & \multicolumn{5}{|c|}{ Thickness of the sample, mm } & \multicolumn{5}{|c|}{ Weight of the sample, mg } \\
\hline & & \multicolumn{2}{|c|}{$\begin{array}{c}\text { Diameter of } \\
\text { the upper } \\
\text { hemispheres }\end{array}$} & \multicolumn{2}{|c|}{$\begin{array}{c}\text { Diameter of } \\
\text { the lower } \\
\text { hemispheres }\end{array}$} & \multirow{2}{*}{$\frac{\vec{n}}{\pi}$} & \multicolumn{2}{|c|}{$\begin{array}{c}\text { Diameter of } \\
\text { the upper } \\
\text { hemispheres }\end{array}$} & \multicolumn{2}{|c|}{$\begin{array}{c}\text { Diameter of } \\
\text { the lower } \\
\text { hemispheres }\end{array}$} & \multirow{2}{*}{$\frac{. \bar{n}}{\pi}$} \\
\hline & & Apex & $\begin{array}{l}\text { Side } \\
\text { wall }\end{array}$ & Apex & $\begin{array}{l}\text { Side } \\
\text { wall }\end{array}$ & & Apex & $\begin{array}{l}\text { Side } \\
\text { wall }\end{array}$ & Apex & $\begin{array}{l}\text { Side } \\
\text { wall }\end{array}$ & \\
\hline 1 & $\begin{array}{l}\text { "Musaffo } \\
\text { Tola 1" } \\
\text { (spring) - } \\
\text { Tashkent }\end{array}$ & 0.82 & 0.76 & 0.66 & 0.72 & 0.8 & 4.2 & 4.2 & 4.4 & 5 & 4 \\
\hline 2 & $\begin{array}{l}\text { "Musaffo } \\
\text { Tola 2" } \\
\text { (spring) - } \\
\text { Tashkent }\end{array}$ & 0.6 & 0.64 & 0.7 & 0.64 & 0.62 & 4.8 & 5 & 4.6 & 5 & 5.2 \\
\hline 3 & $\begin{array}{l}\text { "Musaffo } \\
\text { Tola 1" } \\
\text { (summer) - } \\
\text { Tashkent }\end{array}$ & 0.5 & 0.64 & 0.7 & 0.68 & 0.54 & 3.4 & 4.4 & 4.6 & 4.8 & 3.2 \\
\hline 4 & $\begin{array}{l}\text { "Musaffo } \\
\text { Tola 2" } \\
\text { (summer) - } \\
\text { Tashkent }\end{array}$ & 0.54 & 0.56 & 0.54 & 0.52 & 0.54 & 3.8 & 4.2 & 5 & 4.2 & 4 \\
\hline 5 & $\begin{array}{l}\text { "Jingsong x } \\
\text { Hoayou" } \\
\text { (summer) - } \\
\text { Bukhara }\end{array}$ & 0.52 & 0.48 & 0.46 & 0.52 & 0.56 & 2 & 2.4 & 2.2 & 2.6 & 2.6 \\
\hline 6 & $\begin{array}{c}\text { "Jingsong x } \\
\text { Hoayou" } \\
\text { (summer) - } \\
\text { Ferghana }\end{array}$ & 0.48 & 0.44 & 0.44 & 0.54 & 0.56 & 2.4 & 2.4 & 2.8 & 2.4 & 2.6 \\
\hline
\end{tabular}

If we pay close attention to the figures in Table 4, there is only a significant difference in the thickness of the cocoon shell obtained in the spring and summer seasons of the industrial hybrid "Musaffo Tola 1 " $(0.82 \mathrm{~mm}$ and $0.5 \mathrm{~mm})$. There was almost no difference in shell thickness between "Musaffo Tola 2" and import varieties of hybrids. The weight of the samples showed that the cocoons of the summer season were lighter.

The density and softness of the cocoon shell also in many ways determine the raw silk output, its fineness. Most scientists have noted that the density and softness of the cocoon shell depends on the breed and hybrids of mulberry silkworm. This was explained by the amount of sericine and fibroin in the cocoon shell. If the amount of sericine in the cocoon 
shell is relatively high, such cocoons have been observed to be dense, hard. However, little is known about the effect of high summer temperatures on the density of the cocoon shell and its softness. Table 5 shows the density and softness of the cocoon samples.

Table 5. Density and softness of silkworm cocoon shell (2019-2020)

\begin{tabular}{|c|c|c|c|c|c|c|c|c|c|c|c|}
\hline \multirow{3}{*}{$\#$} & \multirow{3}{*}{$\begin{array}{c}\text { Silkworm } \\
\text { species }\end{array}$} & \multicolumn{5}{|c|}{ Density of the sample, $\mathrm{mg} / \mathrm{mm}^{2}$} & \multicolumn{5}{|c|}{ Softness of the sample, $\mathrm{mm}^{3} / \mathrm{mg}$} \\
\hline & & \multicolumn{2}{|c|}{$\begin{array}{c}\text { Diameter of } \\
\text { the upper } \\
\text { hemispheres }\end{array}$} & \multicolumn{2}{|c|}{$\begin{array}{c}\text { Diameter of } \\
\text { the lower } \\
\text { hemispheres }\end{array}$} & \multirow{2}{*}{$\frac{. \bar{n}}{\pi}$} & \multicolumn{2}{|c|}{$\begin{array}{l}\text { Diameter of } \\
\text { the upper } \\
\text { hemispheres }\end{array}$} & \multicolumn{2}{|c|}{$\begin{array}{l}\text { Diameter of } \\
\text { the lower } \\
\text { hemispheres }\end{array}$} & \multirow{2}{*}{$\frac{\overline{\frac{n}{\pi}}}{\bar{\pi}}$} \\
\hline & & Apex & $\begin{array}{l}\text { Side } \\
\text { wall }\end{array}$ & Apex & $\begin{array}{l}\text { Side } \\
\text { wall }\end{array}$ & & Apex & $\begin{array}{l}\text { Side } \\
\text { wall }\end{array}$ & Apex & $\begin{array}{l}\text { Side } \\
\text { wall }\end{array}$ & \\
\hline 1 & $\begin{array}{l}\text { "Musaffo } \\
\text { Tola 1" } \\
\text { (spring) - } \\
\text { Tashkent }\end{array}$ & 0.66 & 0.86 & 1.19 & 1.13 & 0.74 & 1.72 & 1.48 & 0.85 & 0.97 & 1.72 \\
\hline 2 & $\begin{array}{l}\text { "Musaffo } \\
\text { Tola 2" } \\
\text { (spring) - } \\
\text { Tashkent }\end{array}$ & 2.59 & 2.10 & 1.84 & 2.41 & 1.86 & 0.72 & 0.74 & 1.40 & 0.78 & 0.61 \\
\hline 3 & $\begin{array}{l}\text { "Musaffo } \\
\text { Tola 1" } \\
\text { (summer) - } \\
\text { Tashkent }\end{array}$ & 2.49 & 1.37 & 1.09 & 1.38 & 1.92 & 0.49 & 0.77 & 0.96 & 0.86 & 0.66 \\
\hline 4 & $\begin{array}{l}\text { "Musaffo } \\
\text { Tola 2" } \\
\text { (summer) - } \\
\text { Tashkent }\end{array}$ & 2.18 & 2.55 & 3.21 & 2.68 & 3.83 & 0.60 & 0.60 & 0.47 & 0.44 & 0.66 \\
\hline 5 & $\begin{array}{c}\text { "Jingsong x } \\
\text { Hoayou" } \\
\text { (summer) - } \\
\text { Bukhara }\end{array}$ & 1.49 & 1.97 & 2.46 & 1.86 & 1.35 & 1.02 & 0.63 & 0.65 & 0.76 & 0.90 \\
\hline 6 & $\begin{array}{l}\text { "Jingsong x } \\
\text { Hoayou" } \\
\text { (summer) - } \\
\text { Ferghana }\end{array}$ & 1.77 & 2.70 & 3.88 & 1.42 & 1.33 & 0.60 & 0.48 & 0.49 & 0.90 & 0.98 \\
\hline
\end{tabular}

The density of the cocoon shell and its degree of softness are two opposite indicators. From the figures in Table 5 it can be seen that the density or softness of the cocoon shell in spring and summer depends on the silkworm hybrid. This is because the cocoons grown in the spring of the "Musaffo Tola 1" industrial hybrid are less dense and softer, while in the "Musaffo Tola 2" hybrid the cocoons grown in the summer are denser and harder. As for the performance of the import varieties of hybrid, it can be noted that the same hybrid has a relatively softer cocoon in the hot conditions of Bukhara. Another aspect to note is that the upper and lower hemispheres of the cocoon shell, as well as the density and softness of the lumbar province, show variable results within a hybrid. Such variability means that not all individuals in a hybrid population are the same and have different responses to environmental factors.

The strength and porosity of the cocoon shell also determine the quality of the cocoons obtained. The lower the porosity for cocoon processing enterprises, the higher the yield of raw silk. Based on these, the strength and porosity of the cocoons grown on three different hybrid combinations were determined (Table 6 and Figure 2). 
Table 6. Productivity and porosity of silkworm cocoon shells (2019-2020)

\begin{tabular}{|c|c|c|c|c|c|c|c|c|c|c|c|}
\hline \multirow{3}{*}{ \# } & \multirow{3}{*}{$\begin{array}{l}\text { Silkworm } \\
\text { species }\end{array}$} & \multicolumn{5}{|c|}{ Productivity of the sample, $\mathrm{mg} / \mathrm{mm}^{2}$} & \multicolumn{5}{|c|}{ Porosity of the sample, $\%$} \\
\hline & & \multicolumn{2}{|c|}{$\begin{array}{c}\text { Diameter of } \\
\text { the upper } \\
\text { hemispheres }\end{array}$} & \multicolumn{2}{|c|}{$\begin{array}{c}\text { Diameter of } \\
\text { the lower } \\
\text { hemispheres }\end{array}$} & \multirow{2}{*}{$\frac{\hbar}{\pi}$} & \multicolumn{2}{|c|}{$\begin{array}{l}\text { Diameter of } \\
\text { the upper } \\
\text { hemispheres }\end{array}$} & \multicolumn{2}{|c|}{$\begin{array}{l}\text { Diameter of } \\
\text { the lower } \\
\text { hemispheres }\end{array}$} & \multirow{2}{*}{$\bar{n}^{\frac{n}{\pi}}$} \\
\hline & & Apex & $\begin{array}{l}\text { Side } \\
\text { wall }\end{array}$ & Apex & $\begin{array}{l}\text { Side } \\
\text { wall }\end{array}$ & & Apex & $\begin{array}{l}\text { Side } \\
\text { wall }\end{array}$ & Apex & $\begin{array}{l}\text { Side } \\
\text { wall }\end{array}$ & \\
\hline 1 & $\begin{array}{l}\text { "Musaffo } \\
\text { Tola 1" } \\
\text { (spring) - } \\
\text { Tashkent }\end{array}$ & 0.33 & 0.33 & 0.35 & 0.40 & 0.32 & 70.1 & 67.2 & 61.8 & 59.4 & 70.1 \\
\hline 2 & $\begin{array}{l}\text { "Musaffo } \\
\text { Tola 2" } \\
\text { (spring) - } \\
\text { Tashkent }\end{array}$ & 0.38 & 0.40 & 0.37 & 0.40 & 0.41 & 50.2 & 53.0 & 56.6 & 50.9 & 50.9 \\
\hline 3 & $\begin{array}{l}\text { "Musaffo } \\
\text { Tola 1" } \\
\text { (summer) - } \\
\text { Tashkent }\end{array}$ & 0.27 & 0.35 & 0.37 & 0.38 & 0.25 & 60.3 & 60.4 & 62.2 & 58.7 & 64.9 \\
\hline 4 & $\begin{array}{l}\text { "Musaffo } \\
\text { Tola 2" } \\
\text { (summer) - } \\
\text { Tashkent }\end{array}$ & 0.30 & 0.33 & 0.40 & 0.33 & 0.32 & 57.8 & 54.3 & 44.2 & 52.3 & 52.0 \\
\hline 5 & $\begin{array}{c}\text { "Jingsong x } \\
\text { Hoayou" } \\
\text { (summer) - } \\
\text { Bukhara }\end{array}$ & 0.16 & 0.19 & 0.18 & 0.21 & 0.21 & 76.5 & 70.4 & 70.9 & 70.0 & 73.3 \\
\hline 6 & $\begin{array}{l}\text { "Jingsong x } \\
\text { Hoayou" } \\
\text { (summer) - } \\
\text { Ferghana }\end{array}$ & 0.19 & 0.19 & 0.22 & 0.19 & 0.21 & 70.9 & 67.8 & 60.1 & 73.7 & 72.3 \\
\hline
\end{tabular}

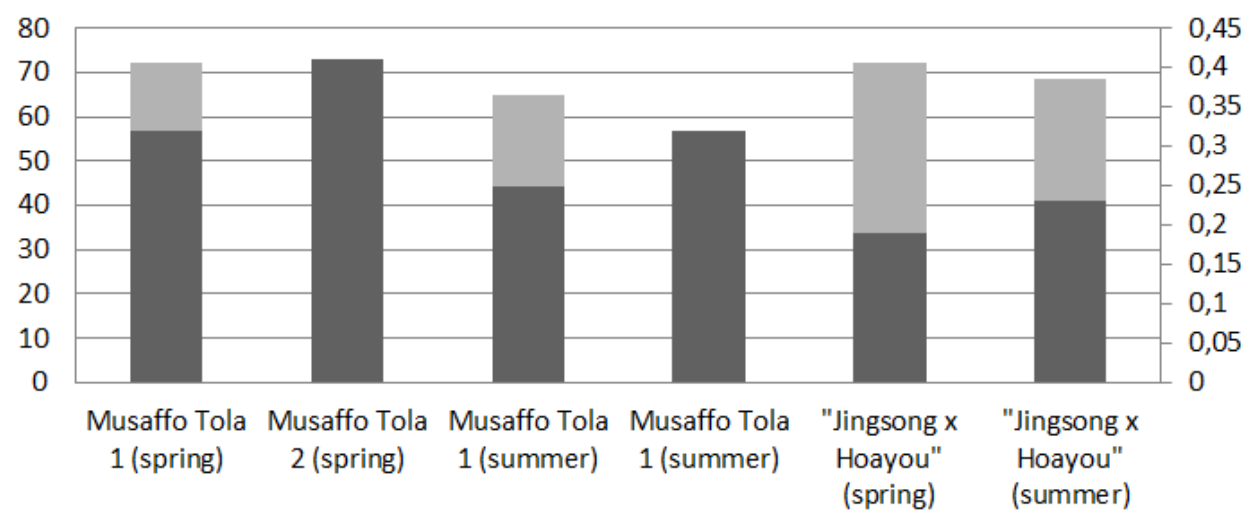

a Porosity of the sample, \% I Productivity of the sample, $\mathrm{mg} / \mathrm{mm} 2$

Fig. 2. Productivity and porosity of silkworm cocoon shells (2019-2020) 
From the data in Table 6 and Figure 2, we can see that the hybrid "Musaffo Tola 1" has a relatively more porous cocoon in the spring. In the case of "Musaffo Tola 2", on the other hand, the porosity was higher in the summer. The porosity of the import varieties of hybrid increases in the warmer conditions of Bukhara. It would also not be methodologically correct to associate this data with $100 \%$ air temperature. In addition to temperature, there are parameters such as nutrient factor and worm feeding area, which also need to be taken into account.

A number of parameters mentioned above do not allow fully determining the effect of high temperature factor on mulberry silkworm hybrids. Indicators such as raw silk yield from hybrid cocoons grown under different conditions, total length of weaved silk fiber (Figure 3), continuous spinning length, degree of spinning and metric number (thinness) of silk fiber can be the basis for the final conclusion.
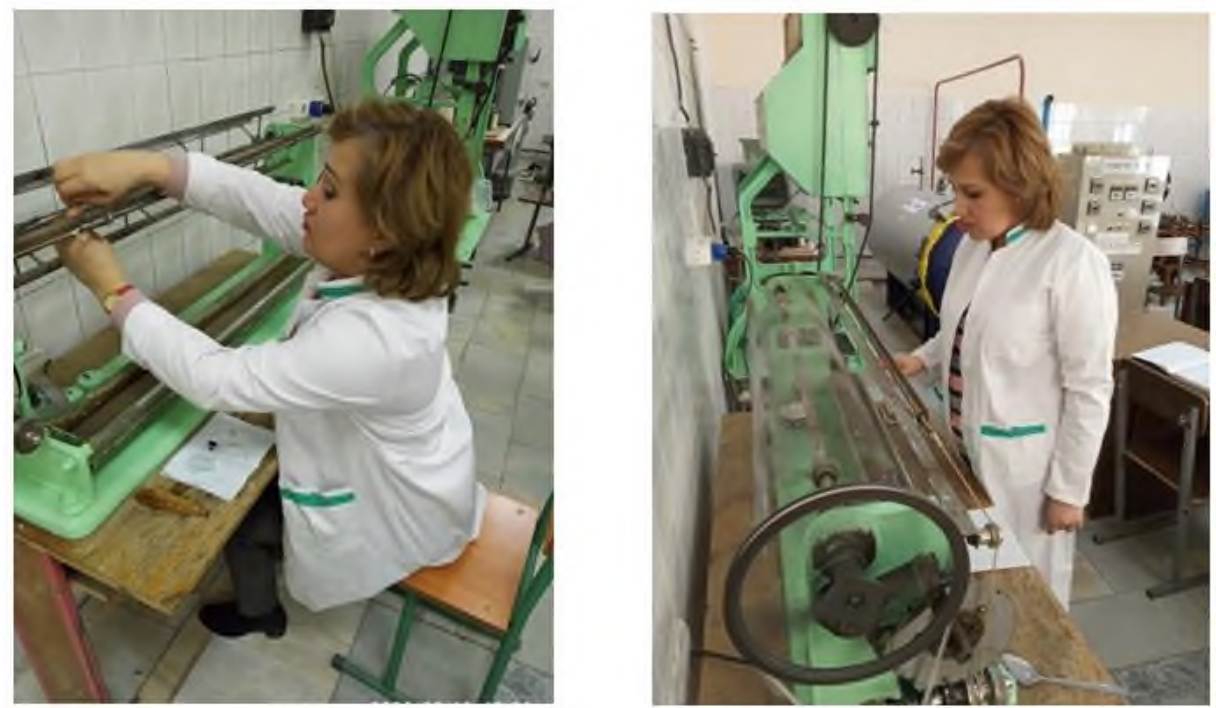

Fig. 3. Weaving process of silk fiber

Based on this, in the spring and summer seasons of 2019-2020, we will collect cocoon samples from industrial hybrids "Musaffo Tola 1", "Musaffo Tola 2" created and provincealized in Uzbekistan and imported to our country "Jingsong x Hoayou" from Tashkent Institute of Textile and Light Industry. Individually in the laboratory, we identified the leading technological indicators (Table 7).

If we start the analysis of the data in Table 7 from the dry cocoon weight indicator, we can see that the cocoons grown in the spring season are heavier than in the summer. This figure is $789.6 \mathrm{mg}$ in the spring in the hybrids "Musaffo Tola 1", "Musaffo Tola 2"; 795.3 $\mathrm{mg}$, while in the summer it was $672.5 \mathrm{mg}$ and $651.7 \mathrm{mg}$, respectively. The difference of the import varieties of hybrid on this indicator in Bukhara and Fergana provinces was 391.5$386.1=5.4 \mathrm{mg}$ - almost the same level was obtained. But local hybrids have confirmed heavy cocoon wrapping in the spring. 
Table 7. Analysis of technological features of individual silk cocoon weaving and cocoon yarn (2019-2020)

\begin{tabular}{|c|c|c|c|c|c|c|c|c|c|c|c|c|c|c|c|c|}
\hline \multirow{2}{*}{ 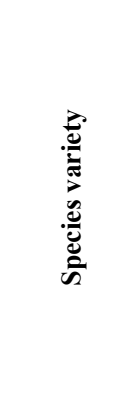 } & \multirow{2}{*}{ 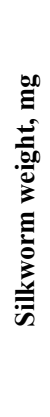 } & \multicolumn{2}{|c|}{$\begin{array}{l}\text { Silk } \\
\text { fiber }\end{array}$} & \multicolumn{2}{|c|}{ Silkworm } & \multicolumn{2}{|c|}{$\begin{array}{l}\text { Silkworm } \\
\text { shell }\end{array}$} & \multicolumn{2}{|c|}{ Cocoon } & \multirow{2}{*}{ 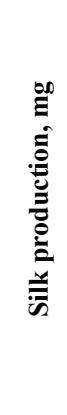 } & \multicolumn{2}{|c|}{$\begin{array}{l}\text { Length } \\
\text { of silk } \\
\text { fiber, cm }\end{array}$} & \multirow{2}{*}{ 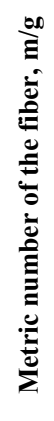 } & \multirow{2}{*}{ 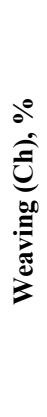 } & \multirow{2}{*}{ 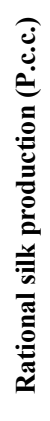 } & \multirow{2}{*}{ 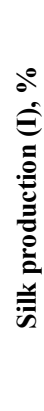 } \\
\hline & & $\stackrel{n a}{\Xi}$ & $\partial^{\circ}$ & $\stackrel{\text { 跑 }}{\Xi}$ & $\partial^{\circ}$ & $\stackrel{\infty}{\Xi}$ & $\partial^{\circ}$ & $\stackrel{00}{\Xi}$ & $\partial^{\circ}$ & & 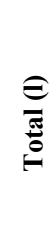 & 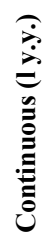 & & & & \\
\hline 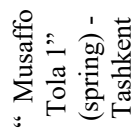 & $\stackrel{0}{\infty}$ & స్రి & $\begin{array}{l}\infty \\
i \\
i\end{array}$ & $\stackrel{\sim}{\sim}$ & $\ddot{m}$ & $\simeq$ & $\stackrel{n}{n}$ & $\begin{array}{c}\stackrel{i}{i} \\
\infty \\
m\end{array}$ & $\underset{+}{+}$ & $\begin{array}{l}m \\
\stackrel{8}{q}\end{array}$ & $\stackrel{\varrho}{ٍ}$ & $\stackrel{\varrho}{ٍ}$ & ते & $\ddot{2}$ & $\underset{\sim}{\stackrel{\infty}{i}}$ & $\hat{i n}$ \\
\hline 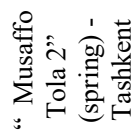 & $\frac{n}{2}$ & $\begin{array}{r}\vec{v} \\
\dot{a} \\
\infty \\
m\end{array}$ & $\begin{array}{l}n \\
\infty \\
\infty \\
+\end{array}$ & $\begin{array}{l}0 \\
\text { i }\end{array}$ & $\stackrel{\infty}{i}$ & $\stackrel{\Xi}{\mathrm{I}}$ & $\stackrel{0}{-}$ & 广̃ & $\stackrel{\infty}{\dot{f}}$ & $\stackrel{+}{\stackrel{\leftrightarrow}{4}}$ & $\begin{array}{l}\mathscr{6} \\
\sim\end{array}$ & $\stackrel{\text { I }}{\mathrm{I}}$ & $\stackrel{\hat{n}}{\hat{n}}$ & $\stackrel{i}{a}$ & $\stackrel{8}{i}$ & ते \\
\hline 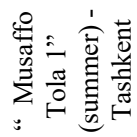 & $\stackrel{n}{i}$ & $\stackrel{\sim}{\stackrel{n}{m}}$ & $\begin{array}{l}n \\
\dot{\sigma}\end{array}$ & $\stackrel{N}{\sim}$ & חై & $\stackrel{n}{=}$ & 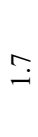 & $\stackrel{n}{n}$ & $\underset{\sim}{\stackrel{\infty}{\sim}}$ & 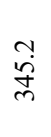 & $\stackrel{\infty}{\beth}$ & $\stackrel{\infty}{=}$ & $\underset{\substack{\infty \\
\infty}}{\infty}$ & $\stackrel{n}{2}$ & $\stackrel{n}{\stackrel{n}{i}}$ & $\frac{n}{n}$ \\
\hline  & $\frac{7}{8}$ & त̂̀ & $\begin{array}{l}\stackrel{t}{\sigma} \\
\dot{\sigma}\end{array}$ & 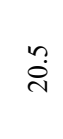 & $\vec{m}$ & $\stackrel{n}{\mathfrak{I}}$ & 9 & 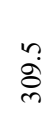 & $\stackrel{n}{\sim}$ & $\vec{m}$ & $\stackrel{8}{0}$ & 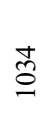 & $\vec{\delta}$ & ֻ̊ & $\stackrel{n}{i}$ & $\frac{n}{n}$ \\
\hline 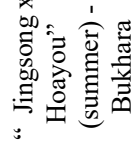 & $\frac{n}{a}$ & 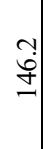 & $\underset{\text { m. }}{\stackrel{0}{m}}$ & $\hat{i}$ & $\ddot{0}$ & $\overrightarrow{0}$ & $\stackrel{\bullet}{i}$ & $\stackrel{\hat{i}}{i}$ & $\vec{\sim}$ & $\stackrel{\circ}{\stackrel{9}{I}}$ & हે & $\stackrel{D}{\infty}$ & $\underset{\overbrace{}}{\stackrel{?}{f}}$ & $\frac{N}{\infty}$ & $\hat{i}$ & ণֶ. \\
\hline 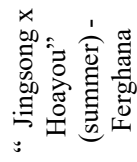 & $\overrightarrow{\dot{0}}$ & $\begin{array}{l}n \\
\vdots \\
0\end{array}$ & $\stackrel{\dot{\vartheta}}{\dot{f}}$ & $\stackrel{\infty}{\sim}$ & $\stackrel{r}{\dot{f}}$ & $\stackrel{n}{r}$ & 9 & $\begin{array}{l}n \\
\infty \\
\infty\end{array}$ & $\frac{n}{f}$ & $\stackrel{2}{\Omega}$ & $\frac{7}{6}$ & 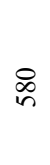 & 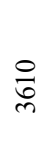 & $\hat{\infty}$ & 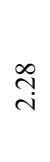 & ñ \\
\hline 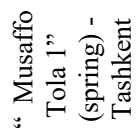 & $\stackrel{\circ}{\stackrel{m}{m}}$ & $\stackrel{\circ}{\sim}$ & ֶ̊. & $\stackrel{ \pm}{d}$ & ช. & 2 & $\stackrel{n}{n}$ & 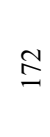 & $\vec{b}$ & 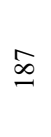 & त్రి & $\frac{n}{6}$ & $\stackrel{m}{\sigma}$ & $\overbrace{\infty}^{1}$ & 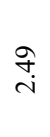 & $\overrightarrow{0}$ \\
\hline
\end{tabular}


Production of raw silk from dry cocoons (cocoon yarn, \%) is an important indicator in the activities of the cocoon processing plant. In our experience, although this figure differed in spring and summer, some hybrid cocoons produced higher results in spring, while other hybrids produced relatively higher results in summer. The yield of raw silk in the spring of the hybrid "Musaffo Tola 1" was $45.8 \%$, and in summer - $46.5 \%$. In contrast to "Musaffo Tola 2", it was $48.5 \%$ in spring and $46.4 \%$ in summer. $37.6 \%$ of raw silk was obtained from cocoons of import varieties of hybrids in hot Bukhara and $43.9 \%$ in Fergana province.

The analysis of the total length and continuous spinning length of silk fiber spun from a single cocoon shows that the highest result was found in the spring-fed variant of the hybrid "Musaffo Tola 2". The total length of the fiber was $1363 \mathrm{~m}$, the length of the continuous weave was $1245 \mathrm{~m}$, and the performance of the summer cocoons of the same hybrid was $1090 \mathrm{~m}, 1034 \mathrm{~m}$, respectively. The import varieties of hybrid showed slightly higher results in Bukhara conditions.

In recent years, the high demand for fine silk in the world silk market has prompted many scientists to create breeds and hybrids that produce fine silk fibers. "Musaffo Tola 1" and "Musaffo Tola 2" industrial hybrids are fine-grained silk hybrids, and the effect of hot weather conditions on their properties is of particular scientific and practical importance. An analysis of the metric number of silk fibers shows that hybrids produce thinner silk fibers in the summer. For example, the silk fiber metrics of "Musaffo Tola 1" and "Musaffo Tola 2" industrial hybrids were $3297 \mathrm{~m} / \mathrm{g}$ and $3537 \mathrm{~m} / \mathrm{g}$ in spring, while in summer this figure was $3898 \mathrm{~m} / \mathrm{g}$ and $3601 \mathrm{~m} / \mathrm{g}$, ie the fiber became thinner. A similar situation was confirmed in the import varieties of hybrid. While the metric number of silkworms grown in Bukhara was $4370 \mathrm{~m} / \mathrm{g}$, in the more temperate Fergana province this figure was 3610 $\mathrm{m} / \mathrm{g}$.

Although there was almost no difference between the spring and summer seasons in terms of cocoon germination of local hybrids, the cocoon density of import varieties of hybrid cocoons was $86.9 \%$ in Fergana province and $81.2 \%$ in Bukhara province.

\section{Conclusion}

On the basis of in-depth technological analysis of cocoons obtained from domestic and import varieties of hybrids in the summer and spring, the following conclusions can be drawn:

- $\quad$ high summer temperatures can significantly affect the technological characteristics of mulberry silkworm;

- too hot air temperature may affect the shape of the cocoons, but may cause their caliber to shrink;

- a decrease in the yield of raw silk from cocoons grown in summer conditions was observed, and fiber thinning was detected;

- there is no correlation between cocoon germination and hot temperature.

\section{References}

1. SH. R. Umarov, U. N. Nasirillaev, S. S. Lezhenko, Scientific basis for solving current problems in the field of silkworm breeding, 205-208 (2004)

2. A. V. Korabelnikov, B. A. Mirzakhodjaev, Textile problems 2, 54-59 (2011)

3. N. M. Islambekova, D. A. Ismailov, Textile problems 1, 19-23 (2014)

4. O. S. Akintayo, J. L. Olajide, O. T. Betiku, A. J. Egoh, O. O. Adegbesan, O. O. Daramola, D. A. Desai, eXPRESS Polymer Letters 14(10), 12 (2020) 
5. D. M. Adigezalova, T. F. Iskandarov, In: BACSA - International conference "Climate changes and chemical - the new sericulture challenges", 128-132 (2017)

6. N. A. Begum, M. M. Ahsan, H. K. Basavaraja, M. Rekha, Sericologia 42(4), 473-483 (2002)

7. F. Chen, P. David, F. Vollrath, Journal of Royal Society Interface, 1-10 (2012)

8. G. Manishankar, M. Ujjal, M. Aniruddha, Research Journal of Chemistry and Environment 12(4), 12-18 (2008)

9. SH. Umarov, B. Nasirillaev, N. Rajabov, M. Jumaniyozov, S. Khudzhamatov, A. Batirova, International Journal of Scientific \& Technology Research 9(3), 1142-1151 (2020)

10. SH. Umarov, N. Rajabov, B. Nasirillaev, KH. Fozilova, Solid State Technology 63(4), 244-250 (2020) 